\title{
LITERASI PEMANFAATAN GADGET PADA MASA PANDEMI DI RT 03/RW 01 KELURAHAN KALIABANG TENGAH KOTA BEKASI
}

\author{
Hamida Syari Harahap ${ }^{1}$, Rina Sovianti ${ }^{2}$, Metha Madonna ${ }^{3}$, Arifin S. Harahap ${ }^{4}$ \\ ${ }^{1,2,3}$ Univesitas Bhayangkara Jaya, Jakarta \\ Jl. Harsono Rm Dalam No.46, Ragunan, Pasar Minggu, Kota Jakarta Selatan - 12550 \\ ${ }^{4}$ Fakultas Ilmu Komunikasi, Universitas Esa Unggul, Jakarta \\ Jalan Arjuna Utara Nomor 9, Kebon Jeruk, Jakarta Barat - 11510
}

\begin{abstract}
The pandemic situation due to Covid 19 has made many changes to human activities and patterns of life. The readiness to accept this situation is not easy. Adapting is the best answer for the situation. Adapting to the use of gadgets in various activities is expected to be a solution, especially in the education and economic sectors. Kelurahan Kaliabang Tengah, especially RT $03 / R W 01$, is one of the areas for community service activities that we carry out with the theme of Literacy for the use of gadgets in pandemic situations. Most of the economic activities in this region are trading. This activity is expected to provide citizen knowledge and it is hoped that this knowledge will be adopted. Based on observations, there are two categories of adopters, namely the late majority and laggard. The efforts carried out in this group are to provide concrete examples of the benefits obtained from the use of gadgets in increasing sales, namely that they are not limited by space and time, save more energy and do not require space so that they are more cost-effective and can also sell various types of products.
\end{abstract}

Keywords: Pandemic, use of gadgets, adopter

\begin{abstract}
Abstrak
Situasi pandemi akabat covid 19 telah banyak memberikan perubahan pada aktifitas dan pola hidup manusia. Kesiapan untuk menerima situasi tersebut memang tidak mudah. Beradaptasi merupakan jawaban terbaik untuk situasi tersebut. Beradaptasi terhadap pemanfaatan gadgetdalam berbagai aktifitasdiharapkan jadi solusi terutama pada sektor pendidikan dan perekonomian. Kelurahan Kaliabang Tengah khususnya RT 03/RW 01 merupakan salah satu wilayah kegiatan pengabadian masyarakat yang kami laksanakan dengan tema Literasi pemanfaatan gadget pada situasi pandemi. Aktifitas perekonomian di wilayah ini kebanyakan berdagang. Kegiatan ini diharapkan dapat memberikan pengetahuan warga dan diharapkan mengadopsi pengetahuan tersebut. Berdasarkan observasi diperoleh dua kategori adopter yaitulate majority dan laggard. Usaha yang dilakukan pada kelompok ini adalah memberikan contoh konkrit keuntungan yang diperoleh dari pemanfaatan gadget dalam meningkatkan penjualan yaitu tidak dibatasi oleh ruang dan waktu, lebih menhemat tenaga dan tidak memerlukan tempat sehingga lebih hemat biaya dan juga dapan menjual berbagai jenisproduk.
\end{abstract}

Kata kunci: Pandemi, gadget, adopter

\section{Pendahuluan}

Kelurahan Kaliabang Tengah merupakan kelurarahan yang memiliki wilayah terluas dan dipimpin oleh perempuan. Wilayah ini memiliki jumlah penduduk terbanyak di kota Bekasi. Luas wilayah sekitar 390,7 sekian meter jumlah RW 30 jumlah RT 278 dan kurang lebih jumlah penduduk 92.000. Kelurahan ini di dominasi oleh pendatang sehingga warga di wlayah ini memiliki karakteristik warga yang heterogen. Berbagai permasalahan pun semakin kompleks di wilayah ini. Hal ini membuat pemimpin di wilayah tersebut memerlukan berbagai strategi dalam melaksanakan program pembangunan.

Covid 19 merupakan peristiwa baru di Indonesia yang berdampak pada Pendidikan dan perekonomian di Indonesia. Beberapa sektor perekonomian mati karena situasi ini. Masa pandemi merupakan masa peralihan dan masa sulit yang harus dihadapi oleh warga. Hal ini tentunya tidak boleh membuat warga berhenti dan pasrah dalam menghadapi masalah tersebut.

Kondisi ini tidak terlalu berpengaruh bagi warga RT 03 RW 01. Warga masih saja beraktitifitas. Kebanyakan warga di sini memiliki mata pencaharian berdagang. Berdasarkar penyataan ketua RW 01 yang juga seorang perempuan "warga disini kerjanya kebanyakan dagang keliling. Ibuibunya membantu perekonomian keluarga dengan jual kue, kosmetik, baju. Selaindagang keliling dengan tetap mematuhi aturan protokol Kesehatan yaitu menggunakan masker mereka juga sudah menggunakan whatsapp buat dagang." 
Cara meningkatkan perekonomian warga ini masih sangat sederhana sehingga penghasilan yang diperoleh pun seadanya. Keinginan untuk mengubah cara berdagang yang lebih baik dengan memanfaatkan teknologi digital masih sangat sederhana dan cenderung mempertahankan cara berdagang keliling. Hal ini disampaikan oleh salah seorang ibu yang sudah lanjut usia "saya dagang keliling juga dagangan saya tetep laku yang penting rasanya enak".

Berdasarkan data lapangan yang diperoleh di atas maka penting kiranya untuk memberikan pengetahuan dan pada warga Rt 03/Rw 01 dalam mengatasi perekonomian keluarga terutama pada masa pandemi ini. Hal ini merupakan salah satu tanggung jawab kami sebagai akademisi untuk melaksanakan tridharma perguruan tinggi yaitu pengabdian kepada masyarakat.

\section{Komunikasi dan Perubahan Sosial Perubahan Sosial}

Perubahan sosial menurut Bungin (2008), merupakan proses sosial yang dialami oleh anggota masyarakat serta semua unsur-unsur budaya dan sistem sosial, dimana semua tingkat kehidupan masyarakat secara sukarela atau dipengaruhi oleh unsur-unsur eksternal meninggalkan pola-pola kehidupan, budaya, sistem, sosial lama kemudian menyesuaikan diri atau menggunakan pola-pola kehidupan,budaya, dan sistem sosial yang baru. Sedangkan Rogers dan Shoemaker (1995), perubahan sosial adalah proses dimana terjadi perubahan struktur dan fungsi suatu system sosial.

\section{Komunikasi}

Rogers dan Shoemaker (1986), komunikasi merupakn proses dimana pesan-pesan dioperkan dari sumber kepada penerima. Proses komunikasi ini dikenal dengan istilah S-M-C-R. Simber (Source-S) mengirim pesan (Message- $M$ ) melalui saluran (Channel-C) kepada penerima (Receiver-R).

\section{Kategori Adopter}

Kategori adopter menurut Rogers (1995), dapat dilihat bahwa adopter cepat dalam penelitian ini meliputi innovators, early adopters, dan early. Hal ini ditunjukkan pada Gambar 1.

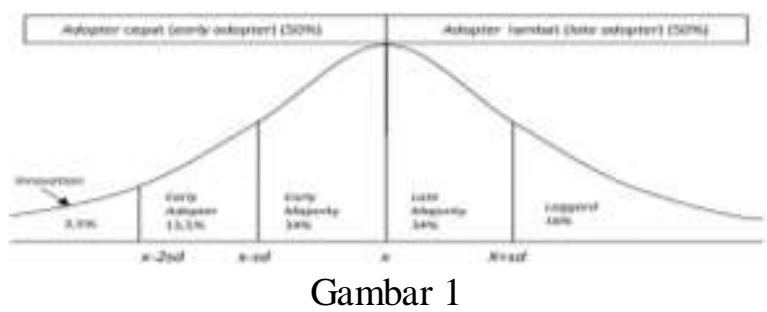

Kategori adopter berdasarkan distribusi frekuensi adopter

\section{Innovators}

Kelompok yang berani dan siap untuk mencoba sesuatu yang baru, Hubungan sosial kelompok seperti ini cenderung lebih cepat dibanding kelompok sosial lainnya. Orang-orang seperti ini lebih mudah membentuk komunikasi yang baik meskipun terdapat jarak geografis. Gaya hidup orang-orang seperti ini biasanya dinamis, tinggal diperkotaan dan memiliki banyak teman atau relasi.

2. Early Adopter

Kelompok ini lebih lokal dibanding kelompok innovator. Kategori adopter seperti ini lebih banyak menghasilkan opini dibandingkan kategori lainnya, serta selalu mencari informasi tentang inovasi. Kelompok ini biasanya disegani dan dihormati oleh kelompoknya karena keikutsertaan mereka dan keinginan mereka untuk mencoba inovasi baru.

3. Early Majority

Kategori kelompok seperti ini tidak mau menjadi kelompok pertama yang mengadopsi inovasi. Sebaliknya mereka akan berkompromi secara hati-hati sebelum membuat keputusan dalam mengadopsi inivasi, bahkan bisa dalam kurun waktu yang lama. Orang-orang seperti ini menjalankan fungsi penting dalam melegitimasi sebuah inovasi atau menunjukkan kepada sebuah komunitas bahwa sebuah inovasi layak digunakan atau cukup bermanfaat.

4. Late Majority

Kelompok ini lebih berhati-hati mengenai fungsi sebuah inovasi. Mereka menunggu hingga kebanyakan orang telah mencoba dan mengadopsi inovasi sebelum mereka mengambil keputusan. Terkadang tekanan dari kelompok bisa memotivasi mereka. Kepentingan ekonomi yang mendorong mereka untuk mengadopsi inovasi.

\section{Lagard}

Kelompok ini merupakan orang yang terakhir melakukan adopsi inovasi. Mereka lebih bersifat tradisional dan segan untuk mencoba hal baru. Kelompok ini biasanya lebih suka bergaul dengan orang-orang yang memiliki pemikiran sama dengan mereka. Begitu kelompok laggard mengadopsi inovasi baru, kebanyakan orang justru sudah jauh mengadopsi inovasi lainnya, dan menganggap mereka ketinggalan zaman.

\section{Metode Pelaksanaan}

Kegiatan pengabdian kepada masyarakat terkait pemanfaatan gadget di masa pandemi ini dilakukan, 4-6 September 2020kepada warga Rt 03 Rw 01, Kaliabang Tengah, Kota Bekasi.Dalam memberikan literasi pemanfaatan gadget kami 
menyampaikan tiga materi yakni menjalin komunikasi melalui gadget, dampak positif dan negative gadget, dan digital marketing.Kegiatan dilaksanakan di aula mushallasecara tatap muka. Media yang kami gunakan da;am memberikan literasi adalah laptop dan infokus. Warga sangat antusias mengikuti kgiatan ini. Jumlah peserta melibihi dari jumlah awal yang kami tetapkan yaitu untuk 30 orang. Materi Pertama yang kami sampaikan adalah jalinan komunikasi melalui gadget.

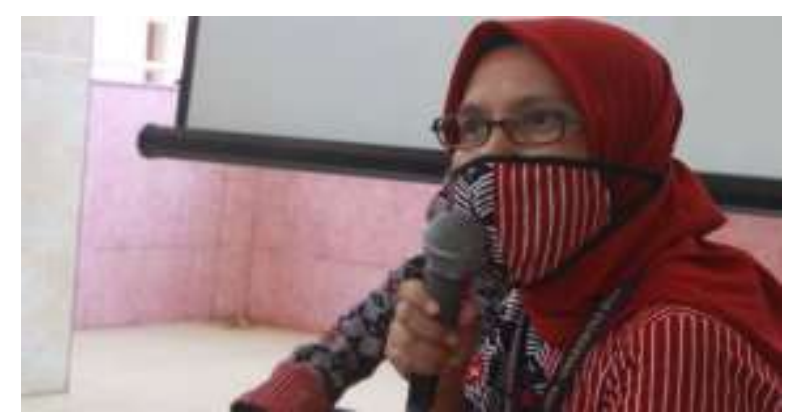

Gambar 2

Penyampaian materi "Jalinan Komunikasi Melalui Gadget"

Materi pertama terkait jalinan komunikasi melalui gadge berisi perubahan perkembangan teknologi informasi dan komunikasi yang begitu cepat, sehingga proses komunikasi pun ikut mengalami perubahan signifikan. Pesatnya kemajuan teknologi telah menumbuhkan perkembangan baru yaitu, kualitas komunikasi semakin ampuh,kualitas bahan komunikasi semakin besar,jangkauan penyebaran semakin luas dan arus penyebaran semakin cepat dan canggih.

Komunikasi memang diperlukan untuk menjalin suatu interaksi dalam masyarakat, syarat terjadinya interaksi harus adanya kontak dan komunikasi. Kontak tidak hanya terjadi secara berhadapan langsung, kontak dapat terjadi melalui perantara, perantara tersebut bisa melalui peralatan. Oleh karena itu, orang dapat mengadakan hubungan komunikasi dengan orang lain tanpa harus bertemu,(Soerjono 1982:58).

Komunikasi dapat berlangsung dari mana saja, baik secara langsung maupun tidak langsung, misalnya dengan menggunakan handphone atau telepon genggam. Saat ini handphone merupakan media komunikasi yang paling banyak digunakan oleh masyarakatSeiring dengan majunya perkembangan teknologi.Telepon genggam juga mengalami perkembangan yang pada awalnya hanya digunakan untuk mengirim dan menerima pesan atau melakukan panggilan maupun menerima panggilan masuk, kini telah dilengkapi dengan fitur internet dan dapat bekerja seperti computer karena itu alat komunikasi ini dianggap sebagai telepon pintar.

Smartphone atau telepon pintar kini menjadi barang yang wajib dimiliki oleh setiap orang, masyarakat saat ini memang sangat antusias untuk menggunakan telepon pintar sebagai alat untuk berkomunikasi dengan sesama. Banyak hal yang dapat kita lakukan dengan menggunakan smartphone, contohnya dalam melakukan komunikasi kita dapat memanfaatkan aplikasi-aplikassi yang terdapat pada telepon pintar seperti LINE, Path,Instagram, $B B M, F B$, whatsapp, Twitteratau bahkan kita dapat berkomunikasi bertatap muka secara langsung dengan orang lain melalui video call. Para pengguna smartphone atau telepon pintar hadir dari latar belakang yang beragam seperti, para pegawai kantoran,ibu-ibu rumah tangga, pelajar dan mahasiswa. Pada saat materi disampaikan tampak ibu-ibu peserta abdimas menyimak materi yang disampaikan dengan seksama..

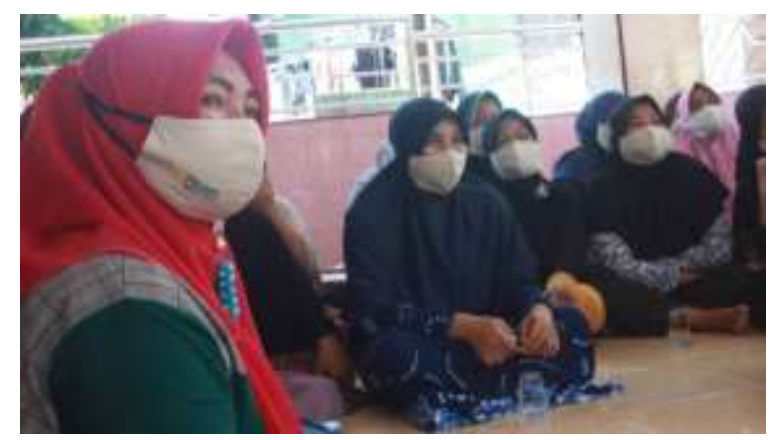

Gambar 3

Ibu rumah tangga menyimak materi "jalinan komunikasi melalui gadget"

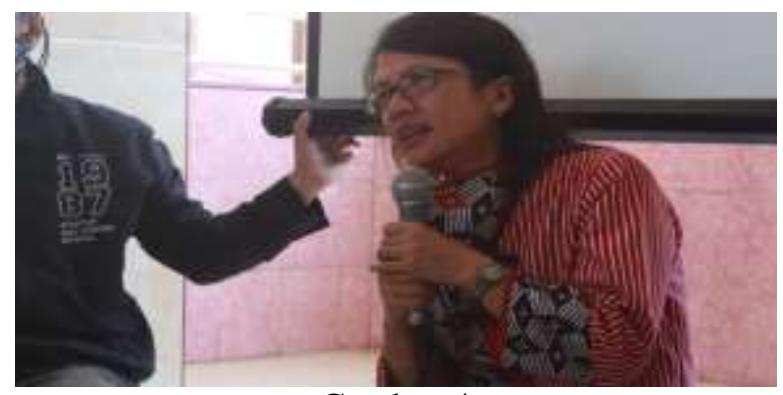

Gambar 4

Penyampaian materi’'Digital marketing"

Materi selanjutnya lebih spesifik yaitu tentangdigital marketing, Digital marketing adalah upaya pemasaran produk dengan menggunakan media digital dan jaringan internet. Banyak kelebihan digital marketing dibandingkan upaya pemasaran tradisional. Kelebihan tersebut adalah kemudahan dalam menjangkau target pasar lebih luas, membutuhkan biaya yang lebih kecil dan menggunakan komunikasi dua arah dengan calon konsumen. 
Digital marketing penting untuk dilakukan karena beberapa alasan berikut:

- bisa digunakan semua jenis bisnis

- meningkatkan pendapatan dengan efektif

- mampu menjangkau target konsumen spesifik

- bisa digunakan apapun perangkat yang digunakan

- dapat membantu membangun brand bisnis Anda

10 tips untuk jualan online terlaris:

1. Kenali nilai unik produk;

2. Ciptakan website toko online;

3. Pelajari data penjualan;

4. Eksekusi content marketing;

5. Aktifkan sosial media;

6. Coba strategi email marketing;

7. Optimalkan word of mouth;

8. Beriklan di channel media sosial;

9. Tarik pelanggan dengan promo;

10. Pikat pelanggan dengan deskripsi produk yang menarik; (https $/ /$ www.seputarmarketing.com/blog/men gapa-digital-marketing-sangat-penting-bagibisnis-anda/)

Setelah materi disampaikan kami membuka ruang sharing. Selain bertanya peserta juga berbagi pengalaman selama mereka berjualan. Pertanyaan pertama dari seorang ibu yang terbilang masih muda. Beliau menanyakan bagaimana cara memasarkan produk dengan menggunakan sophee, apakah berbayar? Kami memberi contoh toko pedia yang juga merupakan market place seperti halnya shopee. Kami menjawab cara memasarkan produk seperti itu tidak berbayar dan tidak bagi hasil. Peserta cukup melakukan registrasi dengan cara online di website. Selanjutnya mengikuti tata cara mendaftar. Lalu memasukkan produk yang dijual dengan deskripsi lengkap Dengan harga yang ditentukan sendiri, saat ada transaksi uang yang ditransfer tidak langsung masuk ke rekening penjual melainkan masuk ke rekening toko pedia. Jika barang jualan sudah dikirimkan melalui ekspedisi yang dipilih penjual melakukan input nomor resi dan apabila barang sudah tiba ditangan pembeli tanpa ada complain maka uang akan ditransfer oleh toko pedia ke penjual.

Setelah pertanyaan pertama kami jawab, ada seorang ibu yang sudah terbilang sudah tua berkomentar tidak pake online juga dagangan tetap laku. Kami menanggapi pernyataan dengan cara memberikan contoh bahwa berjualan dengan menggunakan gadget selain mudah dan lebih mendekatkan diri dengan pelanggan, juga memperoleh beberapa keuntungan tidak perlu menyewa toko atau menumpang dilapak orang lain.
Biaya lebih hemat, produk yang dijual bisa berbagai macam varian, dapat dilakukan dari rumah atau dimana saja jika ada transaksi.

Mendengar penjelasan itu, para peserta mulai paham. Mereka berniat mencoba berjualan melalui online saat pandemi. Selama pandemi transaksi penjualan mereka memang menurun. Para pembeli sepertinya enggan bertransaksi tatap muka karena khawatir covid 19.

Setelah selesai sesi tanya jawab kegiatan ditutup dengan penyerahan sertfikat berupa ucapan terimakasih pada ketua RW 01 Kelurahan Kaliabang Tengah dan sekaligus foto bersama.

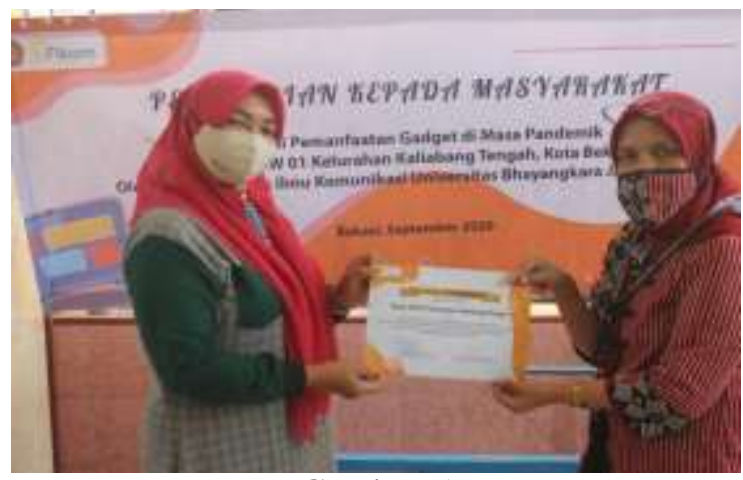

Gambar 5

Penutupan acara dengan serah terima sertifikat ucapan terimakasih

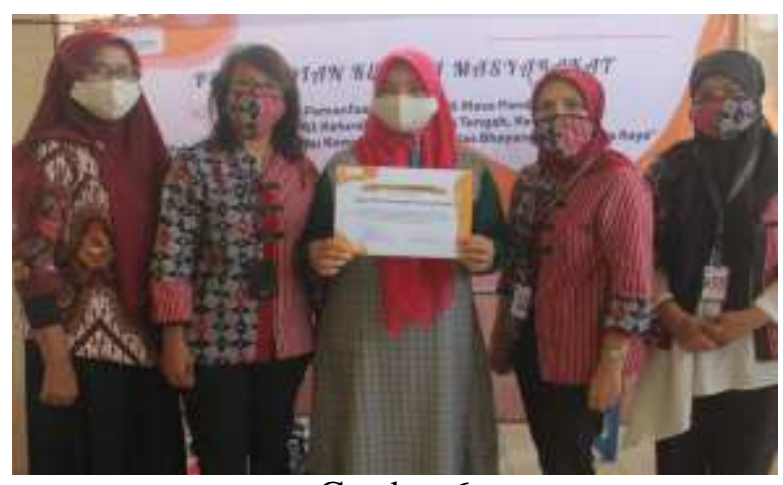

Gambar 6

Foto bersama dengan petugas kelurahan dan Rw 01

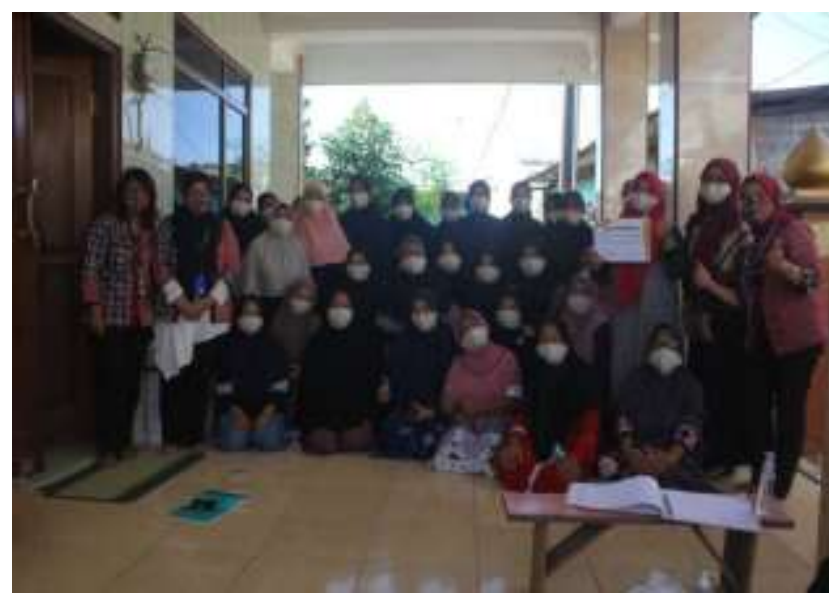

Gambar 7

Foto bersama warga "ibu rumah tangga" 
Hasil dari kegiatan abdimas yang kami juga kami muat di channel Youtube. Berikut :

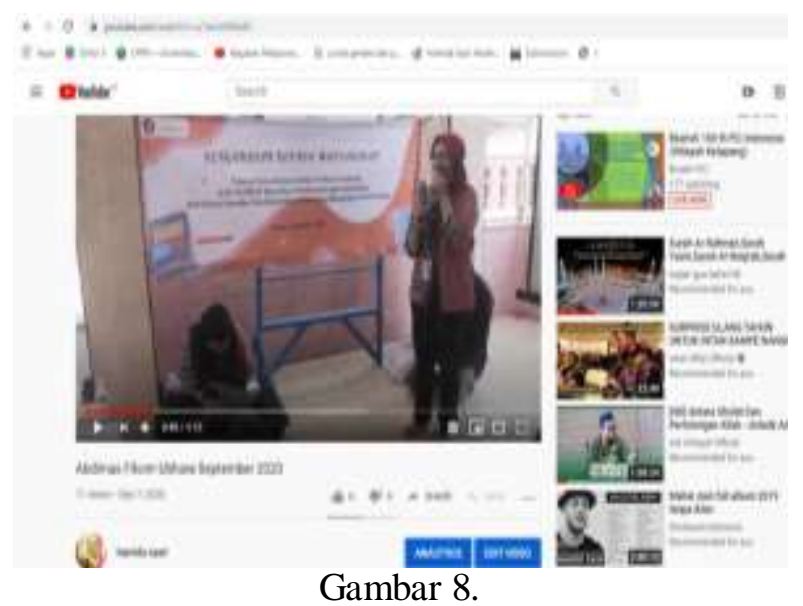

Video di youtube aktivitas kegiatan abdimas

\section{Kesimpulan}

Masa pandemi covid 19 menuntut masyarakat untuk melakukan perubahan pola hidup lama ke pola kehidupan baru. Adaptasi perlu dilakukan untuk bertahan. Dampak covid 19 menyentuh berbagai aspek kehidupan. Baik dari segi pendidikan, perekonomian dan lain-lain. Yang paling dekat dengan keberlanjutan kehidupan adalah perekonomian. Masa covid 19 menuntut kemampuan warga dalam melakukan inovasi.

Literasi pemanfaatangadget ini diharapkan memberikan perubahan pada ibu-ibu rumah tangga yang selama ini berdagang hanya menggunakan whatsaapdan media lain. Bagi ibu-ibu yang bertahan dengan pola lama diharapkan memanfaatkan perkembangan teknologi dengan tujuan penghematan tenaga dan waktu.. kami menyarankan, penjualan dilakukan secara tradisonal dan modern. Keuntungannya bisa dua kali lipat. Pembelian secara langsung dan digital. Dengan digital marketing lebih mendekatkan diri dengan pelanggan,

Melalaui pemasaran digital dapat berjualan berbagai jenis produk. Cara ini lebih efisien, efektif dan jangkauan lebih luas. Targetkonsumen spesifik,bisa dijangkau. Cara ini juga membantu membangun brand bisnis.

Perubahan tidaklah semudah membalikkan telapak tangan. Semua perlu kerja keras dan kemauan untuk melakukan perubahan. Intinya zaman berubah, maka strategi pemsaran juga harus diubah bila mau sukses. Prinsip ini kami tanamkan kepada para peserta.

\section{Daftar Pustaka}

Bungin (2008). Sosiologi Komunikasi, Jakarta: Kencana.
Rogers dan Shoemaker. (1995). Communication of Innovation. Program Pasca Sarjana IPB.

Soekanto, Soerjono (2012). Sosiologi Suatu Pengantar. Jakarta: Rajawali Pers.

https://www.seputarmarketing.com/blog/mengapadigital-marketing-sangat-penting-bagibisnis-anda/ 